\title{
"Say you want a revolution": A Call for Participatory Approach in EFL Educational System
}

\author{
Marzieh Rafiee (Corresponding author) \\ English Department, University of Isfahan, Iran \\ E-mail: rafieemarzieh@gmail.com \\ Mahbube Keihaniyan \\ Young Researchers and Elite Club, Najafabad Brach, Islamic Azad University, Najafabad, Isfahan, Iran \\ E-mail: m_keihaniyan@yahoo.com
}

Doi:10.7575/aiac.alls.v.5n.1p.112

URL: http://dx.doi.org/10.7575/aiac.alls.v.5n.1p.112
Received: 07/01/2014

Accepted: 26/02/2014

\begin{abstract}
This mixed-method study investigated the language teachers' opinions on the inclusion of the principles of Participatory Approach in language classroom settings in Iran. Applying both quantitative and qualitative approaches of data collection procedures, the study explored the language teachers' attitude, on the perceived importance and use of the principles of Participatory Approach in two settings of high schools and private institutes. The results indicated that although both groups of teachers perceived the importance of inclusion of this approach in language classrooms, language teachers working in schools encounter some insurmountable obstacles in their teaching context. The problems of inclusion of Participatory Approach in both settings were then discussed by the teachers and the solutions were offered. Implication for further research is also suggested.
\end{abstract}

Keywords: Participatory Approach; Freirian Critical Pedagogy; Mixed Method Study; EFL Teachers; Language Teaching Context

\section{Introduction}

The struggle for democracy is the centerpiece for the struggle for liberation. Yet it is also clear that democracy has different meanings for different peoples throughout the world. For some, it is synonymous with capitalism, the propagation of acquisitiveness and greed, the barbaric practices of colonialism, and conceptually opposed to socialism. For others, it is a process of achieving equality of social justice for all peoples through popular sovereignty. Paulo Freire (1993, p. XI)

Rooted in the "free school" movement and "Frankfurt school" of social critique and "Marxian critique" that emerged during Cold War years, Critical Pedagogy called for an anti-establishment revolution in the schools which seemed to be looking for inspirations for some changes. Proponents of Critical Pedagogy endorse the students' ability of critical thinking about their educational environment; this way of thinking allows them to engage in a continuous process of "unlearning", "relearning", "evaluation" and "reflection" which help students take a constructive actions during language learning (Shor, 1980). The prime concern of Critical Pedagogy is with criticizing the schooling in capitalist societies. Meanwhile, it attempts to advocate more attention to awareness raising and rejection of violation and discrimination against people (Hall, 2000); a goal which was pursued in Participatory Approach to language teaching.

Participatory Approach (henceforth PA), which was originated in the work of Paulo Freire in the late 1950s, developed a problem posing method in education. The approach is based on the belief that education plays a pivotal role in the development of learner' 'critical consciousness' towards their positions in the society, as well as their abilities for a social change. The core principles of PA, i.e. "people-centered and people-first" tenet, was firmly grounded in the belief that "education and knowledge have value only so far as they help people literate themselves for the social conditions that oppressed them" (Larsen-Freeman \& Anderson, 2011:171). Freire was the critic of what he called "banking" concept of education. He notes that this method of language teaching "transforms students into receiving objects. It attempts "to control thinking and action, leads men and women to adjust to the world, and inhibits their creative power" (Freire, 1970, p. 77). An opposing attitude toward this model is problem posing, which involves the selection of real-life issues from the students' lives and engages the students in an open-ended process of problem solving (Larsen-Freeman \& Anderson, 2011).

In recent years, considerable concern has been arisen over the issue of transformative approaches to education. (Anani Sarab, 2010). Annani Sarab (2010) argues that student-centered approaches to education have been emphasized by practitioners in the field but what we need is a change of focus in teacher training programs. Teachers are not equipped 
enough with the skills they need to enhance the self confidence of students to apply their own experience of community. A glance through the educational system in Iran shows that teachers are merely the followers and consumers of policies mandated by the authorities; an outside source which determines the instructions for teachers inside the cycle of language teaching (Aliakbari \& Allahmoradi, 2012). What make the situation even more problematic are the reasons why student-teachers desire to be teachers. Freire describes teachers as "cultural workers" who are supposed to be productive to engage students in humanization. The approach of problem posing/problem solving suggested by Freire $(1970,1973)$ was intended to humanize the educational experiences of teachers and pupils. The question that looms over us is how we can change the view points of language teachers during their teaching training courses towards the principles of transformative approaches to education. To accomplish this goal, teachers' attitude towards the issue should be investigated. Although several attempts have been made to bring this issue to the foreground (Momenian \& Shirazizadeh, 2009; Akbari, 2008, Ghahremani-Ghajar \& Mirhosseini, 2005), there is still space for more research in this regard. Taking previous studies in the field as a starting point, the present study sets out to find answer to the following research questions:

1. What are the language teachers' (working in schools and institutes) attitudes towards the importance of applying the principles of Participatory Approach in the English Language courses?

2. What are the language teachers' (working in schools and institutes) attitudes towards the perceived use of applying the principles of Participatory Approach in the English Language courses?

3. What would be the probable obstacles of the inclusion of this approach in the context of language teaching?

\section{Method}

In this study, data was gathered based on applying questionnaire and face-to-face interviews, in order to be sure about the integrity and quality of the inferences being made (Schreiber \& Asner-Self, 2011).

\subsection{Questionnaire Participants}

A total number of 84 male/female EFL high school and private institutes' teachers took part in this study. They range in age from 26-40 and their experience of teaching range from 10 to 24 year. They were required to fill out a questionnaire on the perceived importance and use of the principles of PA in schools and institutes. Table 1 offers detailed information of the sample chosen.

Table 1. questionnaire participants

\begin{tabular}{cclclclc}
\hline Gender & & Age & \multicolumn{3}{c}{ Degree } & \multicolumn{2}{c}{ Teaching experience } \\
\hline Male & $\mathbf{2 8}$ & Twenties & 12 & English Teaching & 34 & Less than 5 years & 16 \\
Female & $\mathbf{5 6}$ & Thirties & 42 & English Translation & 33 & $5-10$ years & 29 \\
& & Forties & 24 & English Literature & 14 & 10-15 years & 23 \\
& & Fifties & 6 & Linguistic & 3 & 15-20 years & 9 \\
& & & & & & More than 20 & 7
\end{tabular}

Total

84

\subsection{Interview Participants}

Participants were selected based on purposeful sampling. Open-ended and in-depth interviews were conducted with five teachers in this study. In order to select participants, three criteria were taken into consideration: (a) they voluntarily took part in this study; (b) they should have filled out the questionnaire before; (c) they should have had experience of teaching the English language at schools for at least five years. The detailed information on the participants in the interview is shown in Table 2.

Table 2. Interview participants

\begin{tabular}{lllll}
\hline No. & Gender & Age & Degree & Teaching Experience \\
\hline $\mathbf{1}$ & Female & 42 & English Teaching & 24 \\
$\mathbf{2}$ & Female & 34 & English Teaching & 16 \\
$\mathbf{3}$ & Male & 47 & English Teaching & 29 \\
$\mathbf{4}$ & Female & 35 & English Translation & 17 \\
$\mathbf{5}$ & Male & 33 & English Translation & 15 \\
\hline
\end{tabular}

\subsection{Data collection and analysis}

Being composed of two sections, the questionnaire (adopted from Larsen-Freeman, 2011) was designed to inquire information about the educational background and teaching experience of language teachers in one section, and their 
opinions about the perceived importance and perceived use of PA principles at schools and institutes. The instrument consists of 11 items on Liker scale of four and explores the perceived importance and use of principles of PA in language classrooms in schools and private institutes. The administration process was done both via email and by hand. A face-to-face interview, as a complementary data collection procedure, was conducted as well, to provide "an in-depth look at context, processes, and interactions" and to give a clear image of participants' attitude and perceptions. (Lodico, Spaulding \& Voegtle, 2006, p. 282). The interviews were done in participants' first language, Persian, "thus removing concerns about the proficiency of the learner impacting the quality and quantity of the data provided" (Mackey and Gass, 2005 p. 174). The interview sessions were tape-recorded, transcribed and then back-translated into English. They were read and re-read many times by the researchers in order to find the pattern in the participants' speech. The results are presented in the following section.

\section{Results and Discussion}

\subsection{Questionnaire}

The results of teachers' perception questionnaire show that the importance of employing the principles of PA has been perceived and ranked high by both groups of teachers, with the difference that in institutes, teachers perceived the importance more. The descriptive analysis of results is presented in Table 3.

Table 3. Descriptive analysis of perceived use of PA principles in both settings

\begin{tabular}{|l|r|r|r|r|r|}
\hline & \multicolumn{1}{|c|}{$\mathrm{N}$} & Minimum & Maximum & \multicolumn{1}{c|}{ Mean } & Std. Deviation \\
\hline Schools & 43 & 2.64 & 3.36 & 3.0085 & .20017 \\
institutes & 41 & 2.82 & 3.64 & 3.2373 & .21015 \\
Valid N (listwise) & 41 & & & & \\
\hline
\end{tabular}

As the table demonstrates, the mean score for both sets of teachers' opinions are quite the same. The results of the responses private institutes' teachers gave to the same questionnaire found that the mean score of this group was higher, compared to the school teachers' set, indicating that the probable use of PA principles in the institute classroom context is higher. Table 4 shows the results of descriptive analysis of this group.

Table 4. Descriptive analysis of perceived use of PA principles in both settings

\begin{tabular}{|l|r|r|r|r|r|}
\hline & $\mathrm{N}$ & Minimum & Maximum & \multicolumn{1}{c|}{ Mean } & Std. Deviation \\
\hline school & 43 & 1.55 & 2.82 & 2.0994 & .30008 \\
institute & 41 & 2.73 & 3.91 & 3.4368 & .44220 \\
Valid N (listwise) & 41 & & & & \\
\hline
\end{tabular}

The following figure demonstrates the differences between these two sets in both settings.

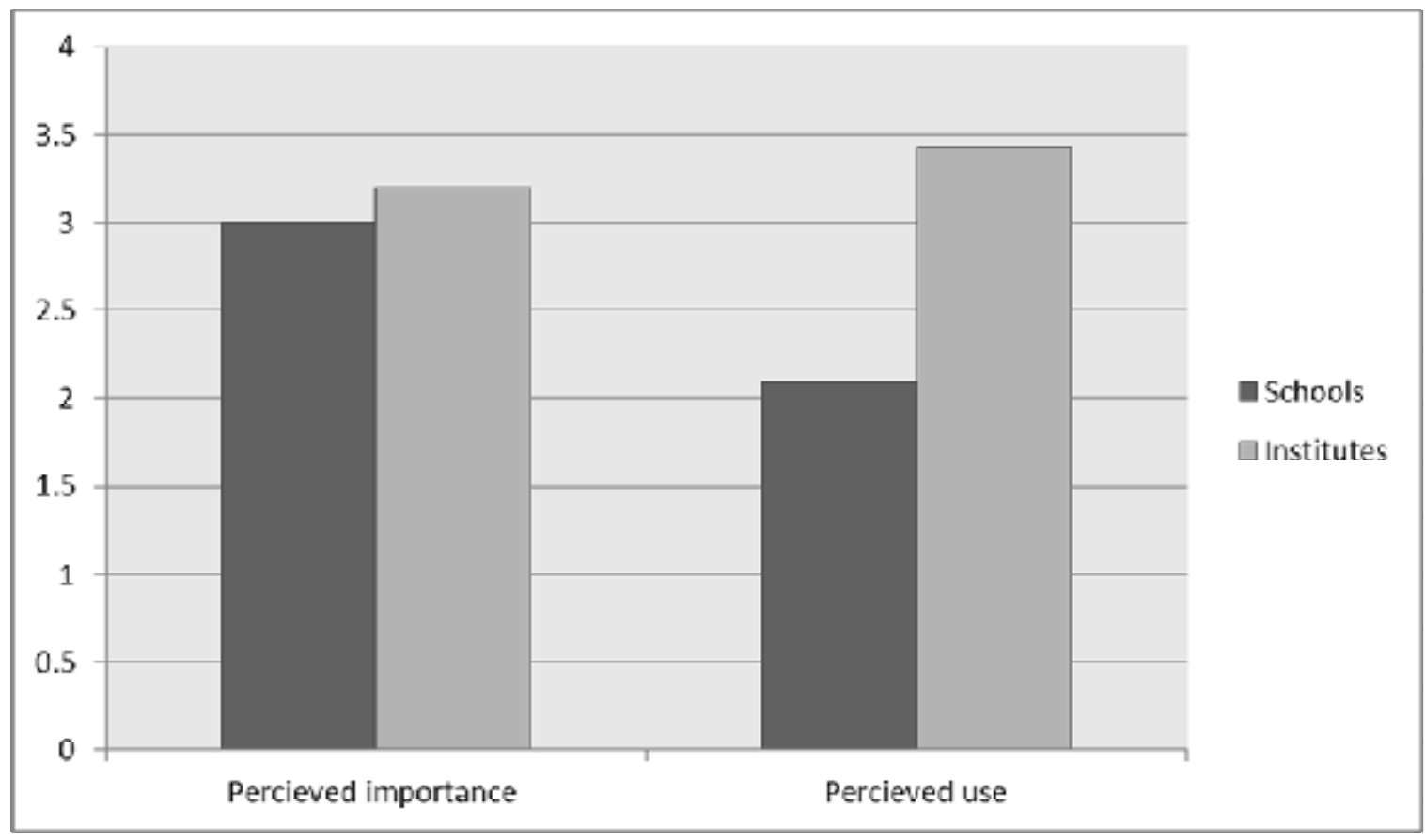

Figure 1. perceived importance and use of PA in schools and institutes 
The answer to the third question was given by the analysis of participants' responses to the interviewer questions. The tape-recorded conversations with the language teachers provide us with further and deeper insight about the perceived importance and use of this method in language classrooms. Comparing to questionnaire results, the interviewees strongly had an agreement on the importance of the principles of PA in school contexts, while the use of these principles in the educational setting was argumentative among the teachers. There are three broad categories of obstacles teachers faced in educational system, which are summarized here:

\subsubsection{The curriculum and syllabus}

As one of the first problems teachers should handle with is the curriculum and syllabus they should follow and cover in the classroom. Being regarded as a widespread problem for language teachers in the classroom, covering all the components of syllabus gives teachers a little chance to work with other aspects of language. One of the basic components of PA is that the curriculum is not a predetermined product, but is built in a jointly-constructed and context-specific problem-posing process (Larsen-Freeman \& Anderson, 2011). There was groans and moans among teachers who complaints about the far-reaching contents of course materials whose basis was the old-fashioned theories of language learning. This point is clearly reflected in the words of interviewee 1, who has the experience of teaching for 24 years in schools:

I remember when I was a university student, over 20 years or so, our heads were complied with a bulk of methods of teaching which we were studying in the books. You know, there were GTM, Audiolingualism, Direct Method, Suggestopedia, and others. I know there are lots of other methods introduced in the field, which are more fruitful and practical, but our teaching still is influenced by those old-fashioned teaching methods. We are surrounded with a lot of "musts"! We must teach the course materials then we must evaluate our students based on some criterions. That's why we cannot improve!

\subsubsection{The role and relationships of teachers and students}

In critical pedagogy and more specifically in PA of teaching, students have a voice in the process of their own learning (Shor, 1996). They are actively involved in knowledge-construction and the education is experienced-centered (LarsenFreeman \& Anderson, 2011). Fortunately because of the dominant effects of student-centered approaches of language teaching, teachers are experiencing a changed role in the educational setting. This is reflected in the following exert, quoted one of the teachers who had the experience of teaching in both schools and institute and compared the role of teachers in both contexts:

Institute teachers are trained in a way that they have a friendship with students, the way they have a role in the students' lives. This is so great, so great! I mean, if a teacher can remove herself/himself from the teacher-centered approaches and make a contact with students' interests, it would be so fruitful! It doesn't mean that school teachers are unable to do this! They can, but curriculum, to be honest, doesn't allow teachers do anything they want in the classroom!

\subsubsection{Language learning facilities}

What were of concern for teachers were the course books and the curriculum, making them far away from the changes recently advised to be done in the language classrooms. Almost all the interviewees agree that we can give students some chance to be involved in the process of their language learning. One of the interviewee brings the example of those schools which are pioneer in this aspect:

In some special kinds of schools (private institutes, Shahed schools, Nemoone-mardomi Schools, etc) in which teachers are equipped with more facilities for teaching English, I think, teachers have more freedom to work on students' social and political beings! This is happening nowadays, although not ubiquitous! These teachers have more time to cover the syllabus and therefore they can work with other aspects of language!

\section{Concluding remarks and implications}

The present study aimed at investigation of EFL teachers' opinions of inclusion of PA principles in two settings of public schools and private institutes. The overall findings of the study demonstrated that employment of the principles of PA in language classrooms is greatly appreciated by language teachers in both settings, despite the fact that language teachers working in public schools have groaning and moaning about the obstacles preventing them to apply the principles in an effective and efficient way. Among the factors they mentioned for these obstacles in one-to-one interviews, they mentioned the tough curriculum and syllabus they should handle in the classrooms, the slow-changing role of teachers and language learners in the context, despite the growing interest in learner-centered approaches to language teaching and at last, but not least, lack of prerequisite facilities in public schools which would result in lack of time and motivation to work on other aspects of language not covered in the syllabus.

Findings of this piece of research might be of help to syllabus designers, curriculum planners, material developers and language teachers, at the top of this list, to take a sober look at the issues related to Critical Pedagogy, especially PA which is the results of applying principles of Critical Pedagogy to TESOL, and try to overcome the difficulties on the way of inclusion of PA in the context. More works need to be done on the inclusion of this approach in other context, such as academic context, and the opinion of language teachers, and the obstacles of facing those contexts could be 
explored. Besides, due to increasing tendency to work out the principles of Critical Pedagogy in Iranian EFL context (Anani Sarab, 2010; Sadeghi, 2008) other studies can work on broader issues in the politics of TEFL, such as additive rather than subtractive language learning, supporting multi-competence in English language use as opposed to enforcing native-speaker use and using non-native speakers as teachers (Giroux, 2011).

\section{Reference}

Akbari, R. (2008). Transforming lives: introducing critical pedagogy into ELT classrooms. ELT Journal , 62 (3), $276-$ 83.

Aliakbari, M., \& Allahmoradi, N. (2012). On Iranian School Teachers' Perceptions. International Journal of Critical Pedagogy, 4 (1), 154-171.

Annani-Sarab, M. (2010). Anani Sarab, M Practice Reading: A Foundation English Course for University Students, Book 2. Tehran: Shahid Beheshti University Press.

Freire, P. (1973). Education for Critical Consciousness. New York: Seabury Press.

Freire, P. (1993). Pedagogy of the City. New York: Continuum .

Freire, P. (1970). Pedagogy of the Oppressed. New York: Continuum/Herder and Herder; Middlesex, UK: Penguin.

Ghahremani-Ghajar, S., \& Mirhosseini, S. A. (2005). English class or speaking about everything class? Dialogue Journal Writing as a critical EFL literacy practice in an Iranian high school. Language, Culture and Curriculum,18 (3), 54-65.

Giroux, H. (2011). On Critical Pedagogy. New York, NY: Continuum Press.

Hall, G. (2000). Local Approaches to Critical Pedagogy: An investigation into the Dilemmas Raised by Critical Approaches to ELT. Linguistics Department, Lancaster University: CRILE Publications.

Larseen-Freeman, D., \& Andreson, M. (2011). Techniques and principles in language teaching. Oxford: Oxford University Press.

Lodico, G. M., Spaulding, D. T., \& Voegtle, K. H. Methods in Educational Reseach: From Theory to Practice. Mackey, A., \& Gass, S. M. (2005). Second Language Reseach: Methodology and Design. London: LAWRENCE ERLBAUM ASSOCIATES, PUBLISHERS.

Momenian, M., \& Shirazizadeh, M. (2009). Putting Things Right: State-of-the-Art on Critical Pedagogy and Writing. MJAL , 1 (4), 223-243.

Sadeghi, S. (2008). Critical Pedagogy in an EFL Teaching context :An ignis fatuus or an Alternative Approach? Journal for Critical Education Policy Studies , 6 (1), 277-295.

Schreiber, J. B., \& Asner-Self, K. (2011). Educational Research: The Interrelationship of Questions,Sampling, Design, and Analysis. United States of America: JOHN WILEY \& SONS, INC.

Shor, I. (1980). Critical Teaching and Everyday Life. Boston, Massachusetts: South End Press.

Shor, I. (1996). When Students Have Power: Negotiating Authority in a Critical Pedagogy. Chicago: University of Chicago Press. 